\title{
Implementation of the Community Peace and Order and Public Safety Program in Negros Occidental, Philippines
}

\author{
Rhumyla G. Nicor-Mangilimutan, ${ }^{1}$ Maria Nove A. Mejica, ${ }^{2}$ and Merlita V. Caelian ${ }^{3}$ \\ ${ }^{1}$ Local Government Unit of La Castellana, Negros Occidental, Philippines \\ ${ }^{2}$ Department of Interior and Local Government Provincial Office, Negros Occidental, Philippines \\ ${ }^{3}$ University of Negros Occidental-Recoletos, Bacolod City, Philippines
}

\author{
Article history: \\ Submitted: 30 October 2020 \\ Revised: 13 December 2020 \\ Accepted: 31 December 2020

\section{Keywords:} \\ Public administration \\ Peace and order \\ Public safety \\ Crime prevention and control \\ Anti-illegal drugs \\ Enforcement of ordinances \\ Descriptive-comparative \\ Negros Occidental \\ Philippines
}

ABSTRACT. Peace is indivisible and global because it is the foundation of the survival of humanity. Ensuring peace and security of the people is vital in maintaining economic development, social order, and political stability. In the Philippines, the functionality of community peace and order and public safety (POPS) is strictly monitored by the government. This descriptive-comparative study assessed the extent of implementation of the POPS in terms of crime prevention and control, anti-illegal drugs, public safety, and enforcement of ordinances. It also investigated the differences in the implementation of the program when the communities are grouped according to variables. Further, it explored the challenges and suggestions of community leaders. Using a researcher-made survey questionnaire, data were gathered from respondents. Findings revealed a great extent of implementation, but there were significant differences when barangays were grouped into variables. The findings were utilized as bases for an enhanced POPS program.

\subsection{Introduction}

Maintaining international peace and security is one of the missions of the United Nations since it came into being in 1945. The fragile structure of inter-state relations, especially regional peace and stability, is crucial in the ASEAN (Severino, 2001).

Studies were conducted exploring the causes of peace and order problems in other countries. Hasam and Mushahid (2017) conducted a sociological study on drug addiction in Bangladesh; Gonis (2018) focused on trends of illicit drug use among the youth in Rwanda, while Wittens (2012) traced the escalation of drug-related violence in Mexico. In the Philippines, Dio, Apostol, and Madrazo (2019) investigated the implementation of project double barrel (PDB), the PNP's anti-illegal drugs campaign plan with a two-pronged approach, targeting high-value targets (HVT) and Project Tokhang, on the surrender of small-time drug dealers. So far, researches conducted did not reveal studies assessing peace and order and public safety programs in the villages of a first-class municipality, where 10 out of the 13 villages registered a low functionality and all 13 showed low functionality on anti-illegal drugs as assessed by the Department of Interior and Local Government (DILG) in 2018. This study aimed to contribute to the body of knowledge on implementing peace and order and public safety programs in villages.

This study determined the extent of implementation of the Peace and Order and Public Safety (POPS) program in the areas of crime prevention and control, anti-illegal drugs, public safety, and enforcement of ordinances. Differences in the extent of implementation were likewise examined when villages were grouped into variables. The findings of the study were utilized in the formulation of an Action Plan for an Enhanced POPS Program to improve the functionality of the program in the villages.

\subsection{Framework of the Study}

This paper theorized that the functionality of the implementation of the Peace and Order and Public Safety (POPS) program by the villages would lead to a peaceful, safe, and habitable community of satisfied residents. Developing and maintaining safe communities, be they rural or urban, populated, or least populated, with higher or lower-income, is central to the issue of good governance. Hence, the study was anchored on the Theory of Good Governance espoused by the World Bank (1992) on applying the principles of public participation, leadership, and efficiency, among others. These principles were instrumental in determining and understanding 
activities implemented at the village level to make far-reaching interventions and mechanisms for policy-making and implementation by knowing the status of implementation and the challenges encountered by community leaders.

The study also adopted the Systems Theory of Ludwig von Bertalanffy. According to this theory, real systems are open to and interact with their environments and focus on the arrangements of and relations between the organizations and connect them into the whole. This theory is highly relevant to this study because the implementation of the POPS program is influenced by its external environment through the participation of the residents and organizations comprising the community, such as civil society organizations and the residents in general. It examined how law enforcement agencies interact with the community to execute their primary responsibility of keeping the peace and order.

\subsection{Methods}

The study used a quantitative research design using descriptive-comparative approaches. A descriptive research design was utilized to describe the extent of the implementation of the different areas of the Peace and Order and Public Safety (POPS) program. The comparative design was used to explain the differences and similarities in the extent of the implementation of the POPS program when the villages were grouped according to geographic location, income, and population (Esser \& Vliegenthart, 2017). The respondents of the study were the 253 community leaders identified through stratified random sampling using the Raosoft online calculator.

To determine the extent of the implementation of the POPS program, a researcher-made survey instrument was utilized. This was based on DILG Memo Circular No. 2017-142 (Guidelines in the Formulation of a Simplified Peace and Order and Public Safety (BPOPS Plan), the Comprehensive Dangerous Drugs Act of 2002, and RA 10121 (Philippine Risk Reduction and Management Act of 2010). Since the questionnaire was researcher-made, it went through validity and reliability tests. The validity test was performed by five (5) experts in program implementation: the Local Government Operations Officers (LGOO) of other local government units using the Good and Scates' criteria. The validity result was 4.08 , which means that the survey questions were very good and interpreted as valid. Reliability was conducted by pilot-testing the instrument to 30 community leaders who were not included in the actual study. Using Cronbach's Alpha coefficients, the reliability test yielded an index of 0.974 , with an interpretation of reliable.

Descriptive analysis using mean and standard deviation was utilized to assess the extent of implementation of the POPS program. To identify the community leaders' challenges and suggestions, the frequency count and percentage were used. Comparative analysis was used to interpret data relating to the differences in implementing the POPS program when the villages were grouped according to the variables. The normality test revealed no normal distribution in the variables; thus, the use of the non-parametric tool, Mann Whitney $U$ test, to determine the significant difference in the extent of implementation of the POPS program.

\subsection{Results and Discussion}

\section{Extent of implementation of the peace and order and public safety (POPS) program}

Tables $1 \mathrm{~A}$ and $2 \mathrm{~B}$ show the extent of implementation of the POPS program. As a whole, implementation is to a great extent $(M=3.95 ; S D=0.74)$, which means that the conditions that promote peace and order and public safety are oftentimes implemented. This finding is similar to the study of Dekanoidze and Khelashvili-Kyiv (2018) on the use of participation by forging a partnership with the community.

Of the four components of the POPS, the highest $(M=4.07$; $S D=0.760)$ interpreted great extent, was crime prevention and control because villages are actively employing strategies such as integrated patrol system, and village peacekeeping operations such as ronda, and barangay tanods, The findings demonstrate that policing is not just enforcing the law; it is part of social work in the community (Dekanoidze \& Khelashvili-Kyiv, 2018; Huey et al., 2017). The implementation of the antiillegal drugs program was rated the lowest, although it was interpreted as a great extent $(M=3.86$; $\mathrm{SD}=1.02$ ) as a whole, while it was rated a moderate extent for high-income villages. 
Table 1A. Extent of implementation of the peace and order and public safety programs

\begin{tabular}{|c|c|c|c|c|c|c|c|c|c|}
\hline \multirow{2}{*}{ Variable } & \multicolumn{3}{|c|}{ Implementation } & \multicolumn{3}{|c|}{$\begin{array}{l}\text { Crime prevention } \\
\text { and control }\end{array}$} & \multicolumn{3}{|c|}{$\begin{array}{l}\text { Anti-illegal } \\
\text { drugs }\end{array}$} \\
\hline & $M$ & SD & Int & $M$ & SD & Int & $M$ & SD & Int \\
\hline \multicolumn{10}{|l|}{ Geographical location } \\
\hline Urban & 3.65 & 0.83 & GE & 3.93 & 0.72 & GE & 3.53 & 1.37 & GE \\
\hline Rural & 4.01 & 0.71 & GE & 4.10 & 0.69 & GE & 3.92 & 0.93 & GE \\
\hline \multicolumn{10}{|l|}{ Income } \\
\hline High & 3.54 & 0.91 & GE & 3.82 & 0.80 & GE & 3.40 & 1.36 & ME \\
\hline Low & 4.06 & 0.65 & GE & 4.15 & 0.65 & GE & 3.99 & 0.86 & GE \\
\hline \multicolumn{10}{|l|}{ Population } \\
\hline Highly populated & 3.67 & 0.84 & GE & 3.92 & 0.74 & GE & 3.55 & 1.19 & GE \\
\hline Less populated & 4.10 & 0.64 & GE & 4.16 & 0.66 & GE & 4.02 & 0.88 & GE \\
\hline Total & 3.95 & 0.74 & $G E$ & 4.07 & 0.70 & $G E$ & 3.86 & 1.02 & $G E$ \\
\hline
\end{tabular}

Note: $M E=$ Moderate Extent, GE=Great Extent

Table 1B. Extent of implementation of the peace and order and public safety programs

\begin{tabular}{|c|c|c|c|c|c|c|c|c|c|}
\hline \multirow{2}{*}{ Variable } & \multicolumn{3}{|c|}{ Implementation } & \multicolumn{3}{|c|}{ Public safety } & \multicolumn{3}{|c|}{$\begin{array}{l}\text { Enforcement } \\
\text { of ordinances }\end{array}$} \\
\hline & M & SD & Int & M & SD & Int & M & SD & Int \\
\hline \multicolumn{10}{|l|}{ Geographical location } \\
\hline Urban & 3.65 & 0.83 & GE & 3.64 & 0.98 & GE & 3.57 & 0.90 & GE \\
\hline Rural & 4.01 & 0.71 & GE & 4.11 & 0.76 & GE & 3.95 & 0.87 & GE \\
\hline \multicolumn{10}{|l|}{ Income } \\
\hline High & 3.54 & 0.91 & GE & 3.56 & 1.02 & GE & 3.47 & 1.00 & GE \\
\hline Low & 4.06 & 0.65 & GE & 4.16 & 0.70 & GE & 4.01 & 0.82 & GE \\
\hline \multicolumn{10}{|l|}{ Population } \\
\hline Highly populated & 3.67 & 0.84 & GE & 3.70 & 0.91 & GE & 3.58 & 0.96 & GE \\
\hline Less populated & 4.10 & 0.64 & GE & 4.21 & 0.70 & GE & 4.05 & 0.81 & GE \\
\hline Total & 3.95 & 0.74 & $G E$ & 4.03 & 0.82 & $G E$ & 3.89 & 0.89 & $G E$ \\
\hline
\end{tabular}

Note: $\mathrm{ME}=$ Moderate Extent, $\mathrm{GE}=$ Great Extent

The finding of the moderate extent on the anti-illegal drugs program of the urban villages as revealed by community leaders who viewed the anti-illegal drugs campaign with cynicism considering that those who were caught and surrendered are the lowly and marginalized sectors belonging to informal workers and the jobless who are drug couriers and not high-value targets supporting the studies of Gonis (2018), Hasam and Mushahid (2017), Dio and Apostol (2019), and Madrazo (2019) that the use of illegal drugs has already become a social problem, especially for the urban areas where the environment is conducive to the operation of the illegal drugs. As acknowledged in the study of Wittens (2012), weak institutional capacity, corruption, availability of weapons, poverty, and geographical location, contributed to drug-related violence. The implementation of public safety and enforcement of ordinances were both rated great extent. 


\section{Difference in the extent of implementation of POPS}

Table 2 presents the differences in the extent of the implementation of the POPS when villages were grouped according to geographical location.

Mann Whitney $U$ test revealed significant differences in the extent of implementation of the POPS program $[\mathrm{U}=3062.50, \mathrm{p}=0.003]$, in anti-illegal drugs $[\mathrm{U}=2937.50, \mathrm{p}=0.001]$, public safety $[U=3063.00, p=0.003]$, and enforcement of ordinances $[U=3222.00, p=0.000]$ when villages were grouped according to geographical location. Findings of the study in the case of anti-illegal drugs registered a significant difference with ratings of rural villages slightly higher than urban villages. In small communities, everybody knows each other, and neighbors condemn those who use and engage in illegal drugs.

The finding reinforces the study of Wittens (2012) that geographical location contributed to drug-related violence that exists in a favorable environment such as urban areas. Gonis (2018) also states that the use of illicit drugs was possible because these are available in the area associated with urbanity. Public safety also registered a significant difference with rural villages rating higher than urban villages because concerns such as street lights, fire hazards, traffic, road clearing, and obstructions are not priorities in rural but are primary concerns of the urban villages. Meanwhile, enforcement of ordinances is not of concern for rural villages, as revealed in their slightly higher ratings than the urban villages. However, there were challenges raised by rural communities in all of these areas. The no significant difference in the area of crime prevention and control $[U=3649.50$, $p=0.099]$ is attributed to the effectiveness of the criminal justice system and the dynamic nature of police-community relations practiced by law enforcement agencies in both urban and rural villages employing effective strategies. The results suggest that geographical location plays a significant role in implementing the POPS.

Table 2. Difference in the extent of implementation of POPS programs by geographical location

\begin{tabular}{lcccc}
\hline \multicolumn{1}{c}{ Variable } & Geographical location & U & $\mathrm{p}$ \\
\hline Implementation & Urban & Rural & & \\
& 3.65 & 4.01 & 3062.50 & 0.003 \\
Crime Prevention and control & $(0.83)$ & $(0.71)$ & & \\
& 3.93 & 4.10 & $3640.50^{*}$ & 0.099 \\
Anti-illegal drug abuse program & $(0.72)$ & $(0.69)$ & & 0.001 \\
Public safety program & 3.53 & 3.92 & $2937.50^{*}$ & \\
Enforcement of local ordinances & $(1.37)$ & $(0.93)$ & & 0.003 \\
& 3.64 & 4.11 & $3063.00^{*}$ & \\
\hline
\end{tabular}

Note: ${ }^{*}$ The difference is significant when $\mathrm{p} \leq 0.05$.

When villages were grouped as to income, significant differences were revealed: in crime prevention and control $[U=4110.50, p=0.004]$, anti-illegal drugs $[U=3496.50, p=0.000]$, public safety $[U=3539.00, p=0.000]$, and enforcement of ordinances [3767.00, $p=0.000]$. The findings indicate that the income of the villages is a factor affecting the perceptions of community leaders because the income of these communities translates to the income of the residents. As acknowledged in the study of Habiatan (2019), communities with high income have low to moderate concern on the crime prevention and control programs of the locality, while the middle to low-income communities is participative and aware of the presence of the program in the community. The findings of the study of Habiatan (2019) on the low rating provided by high-income communities compared to low-income communities to crime prevention and control programs are similar to the findings of this study. 
In anti-illegal drugs, the study of Oliveira, Bastos-Filho, and Menezes (2017) validated the findings of this study where low-income communities gave higher ratings than high-income because it was found that high-income communities provided moderate extent of implementation while lowincome communities rated great extent. The inequalities in resources, opportunities, power, the center of trade and commerce, and access to social status available in high-income communities lead to the commission of crimes such as the trade of illegal drugs. Likewise, public safety and enforcement of ordinances registered significant differences when communities were grouped as to income. This finding is aligned with the study of Ghani (2017) that the difference in implementation of the program of some high-income with the low-income communities is attributed to the perception of residents of social inequity, urbanization, and corruption in government.

Table 3. Difference in the extent of implementation of POPS programs by income

\begin{tabular}{lcccc}
\hline \multirow{2}{*}{ Variable } & \multicolumn{2}{c}{ Income } & U & P \\
\hline Implementation & High & Low & & \\
\hline & 3.54 & 4.06 & $3549.00^{*}$ & 0.000 \\
Crime Prevention and control & $(0.91)$ & $(0.65)$ & & \\
& 3.82 & 4.15 & $4110.50^{*}$ & 0.004 \\
Anti-illegal drug abuse program & $(0.80)$ & $(0.65)$ & & \\
& 3.40 & 3.99 & $3496.50^{*}$ & 0.000 \\
Public safety program & $(1.36)$ & $(0.86)$ & & \\
Enforcement of local ordinances & 3.56 & 4.16 & $3539.00^{*}$ & 0.000 \\
& $(1.02)$ & $(0.70)$ & & \\
\hline
\end{tabular}

Note: *The difference is significant when $\mathrm{p} \leq 0.05$

When villages were grouped as to population, significant differences were revealed. In crime prevention and control $[U=5894.50, p=0.014]$, anti-illegal drugs $[U=5057.00 p=0.000]$, public safety $[U=4684.50, p=0.000]$, and enforcement of ordinances $[U=5124.00, p=0.000]$. This finding of higher implementation of less populated villages than populated villages which registered a significant difference in crime prevention and control confirmed the study of Welsh and Farrington (2012) that criminal opportunity is abundant in highly populated areas and of Curiel, Delmar, and Bishop (2018) who discovered that small populations suffer a smaller number of crimes similar in this study.

In anti-illegal drugs, a significant difference was found in that there is a higher implementation of drug clearing operations in rural areas where the population is lesser. The findings of Agustin, Rovero, Paraon, Taguinod, and Turingan (2019) that the BADAC is functional in rural areas are also supported by the findings of this study. Further, the significant difference in the area of public safety strengthened the studies of Sackett (2016), and Asor, Catedrilla, and Estrada (2018) that where the population is high, opportunities are present for the commission of crimes on public safety such as traffic violations, obstructions on sidewalks because of street vendors, and violation of flood control programs. In this study, violations of public safety programs in communities that are highly populated are more prevalent than in less populated communities. 
Table 4. Difference in the extent of implementation of POPS programs by population

\begin{tabular}{|c|c|c|c|c|}
\hline \multicolumn{5}{|c|}{ Income } \\
\hline Variable & $\begin{array}{l}\text { Highly } \\
\text { Populated }\end{array}$ & $\begin{array}{l}\text { Less Popu- } \\
\quad \text { lated }\end{array}$ & $U$ & $P$ \\
\hline \multirow[t]{2}{*}{ Implementation } & 3.67 & 4.10 & 4957.50* & 0.000 \\
\hline & $(0.84)$ & $(0.64)$ & & \\
\hline \multirow[t]{2}{*}{ Crime prevention and control } & 3.92 & 4.16 & $5894.50^{*}$ & 0.014 \\
\hline & $(0.74)$ & $(0.66)$ & & \\
\hline \multirow[t]{2}{*}{ Anti-illegal drug abuse program } & 3.55 & 4.02 & $5057.00 *$ & 0.000 \\
\hline & (1.19) & $(0.88)$ & & \\
\hline \multirow[t]{2}{*}{ Public safety program } & 3.70 & 4.21 & $4684.500^{*}$ & 0.000 \\
\hline & $(0.91)$ & $(0.70)$ & & \\
\hline \multirow[t]{2}{*}{ Enforcement of local ordinances } & 3.58 & 4.05 & $5124.00^{*}$ & 0.000 \\
\hline & $(0.96)$ & $(0.81)$ & & \\
\hline
\end{tabular}

Note: *The difference is significant when $\mathrm{p} \leq 0.05$

\section{Challenges encountered in the implementation of POPS when villages are grouped to location}

By geographical location. The top challenge in crime prevention and control is poor access roads to geographically isolated areas. This finding suggests the presence of lawless elements in the hinterlands. The poor road network can cause major delays in police assistance and pose a security threat to responders. According to the United Nations Office on Drugs and Crime (UNODC, 2017), the isolation of rural communities and longer travel distances act as barriers to seeking and accessing services; hence, there is a growing problem in the rural setting. The study of Tollefsen and Buhaug (2015) showed that accessibility is related to life opportunities, such as delivering public goods and services and law and order. This result affirms Ghani's (2017) findings that the perception of social inequality is a cause of indifference of the residents complementing the number one challenge of inadequacy of ratio between the Police and Philippine Army assigned in the villages found in this study. However, rural villages still rated implementation of the POPS great extent slightly higher than the rating in urban villages because the recent programs and projects of the local government focus on rural villages such as the tourism development and the installation of the sub-station of the police in the rural communities.

In anti-illegal drugs, the top-rated challenge is residents are afraid to report information on illegal drugs for rural and $2^{\text {nd }}$ for urban villages affirming study of Alagabia and Cawi (2019) that residents become indifferent to such programs. The lack of appropriate seminars to the BADAC for rural villages disputes the study of Agustin et al. (2019) that village officials are well aware of their duties and responsibilities in the anti-drug clearing operations. The absence of community-based rehabilitation program, was identified by both groups as the lowest-rated challenge, established the validity of the claim that residents are afraid to report or provide information because the villages cannot provide rehabilitation; instead, drug dependents are put in jail which is a stigma to the family.

On public safety, the challenges are lack of resources to implement the program, such as lack of rescue equipment for rural villages and lack of traffic enforcers for urban villages. Both groups identified illegal parking as one of the highest-rated challenges and lack of community volunteers as their lowest-rated challenge. Although this finding is the lowest in both classes of villages, it was revealed that regardless of geographical location, poverty prevails in the communities considering that volunteer work is not their priority.

The enforcement of local ordinances has also identified challenges: poor enforcement of ordinances and lack of awareness of the community were rated highest affirmed the study of Habiatan (2019) that peace and order council members in the villages have moderate participation in the maintenance of peace and order. 
By barangay income. Low and high-income communities identified poor access roads to geographically isolated areas as the topmost and second challenge in crime prevention and control. This finding aligns with Gichaga (2016) that road safety is significant to residents. Highincome communities believe that crime prevention and control is the primary responsibility of law enforcement agencies. This finding suggests that police units should involve the support of the community aligned with the studies of Dekanoidze and Kyiv (2018) and Huey, Kalyal, and Peladeau (2017).

In anti-illegal drugs, the top challenge is that residents are afraid to report information related to illegal drugs, which indicates that drug addiction has already become a social problem similar to the findings of Hasam and Mushahid (2017) that drug-related laws are not effectively implemented, thereby creating alienation with the residents. This finding is substantiated by the moderate extent rating provided by high-income communities on the implementation of the anti-illegal drugs campaign supported by the absence of a community-based rehabilitation program.

In public safety, both groups identified lack of resources as the number one challenge. Low-income villages identified a lack of rescue equipment. In contrast, high-income villages identified the lack of traffic enforcers as the number one challenge. This finding emphasized the influence of the economic vulnerability of communities to respond to safety, similar to the findings of Yonson, Noy, and Gaillard (2017) that socio-economic development and good local governance reduce vulnerability. Both high-income and low-income villages identified illegal parking as the second-highest challenge, which means that road safety is one economic growth component (Asor, Catedrilla, \& Estrada, 2018).

In the enforcement of ordinances, both groups identified three (3) measures: local ordinances were not properly disseminated, lack of participation during the public hearing, and absence of enforcement teams as challenges which indicate that community leaders are unanimous that implementation, although found in this study as great extent, is moderately functioning as attested in the findings of Habiatan (2019).

By barangay population. Both highly and less populated communities identified poor access road to geographically isolated areas as their number one challenge in crime prevention and control. Though the LGU under study is a first-class municipality, many of its road networks leading "sitios" and haciendas are not fully developed.

In anti-illegal drugs, weak monitoring of illegal drugs in the community was the topmost challenge for a highly- populated communities. Simultaneously, residents are afraid to report information related to illegal drugs for less populated communities. In the area of public safety, the lack of traffic enforcers was the main challenge for highly populated communities. Illegal parking was also another challenge identified. These findings are aligned with the study of Downs (2004), wherein the population is considered a significant factor in traffic congestion.

The lack of rescue equipment was the major challenge identified by less populated communities. Villages have a limited budget; therefore, rescue equipment is prepositioned only at the village center or disaster operation centers. Based on the findings of Layug, Bolong, Lavado and Pantig (2009), most communities are failing expectations, mainly because of financial constraints.

In the enforcement of ordinances, lack of awareness of the community and lack of participation during the public hearing were the top most challenges of highly populated villages. In comparison, poor enforcement of ordinances was the major challenge of less populated communities. Although the result of the implementation of the POPS program is of great extent for both high and less populated communities, there are still challenges identified. It was found that even though Filipinos do not consider fighting criminality as the most urgent concern, peace and order is a top community concern that most Filipinos think local governments should focus on. The sociological study of Chamlin and Cochran (2004) was based on the theory that as population size increases, the frequency of social interactions increases, which revealed that population size significantly affects the number of crimes and that population size is the single predictor of the level of violence and property crime aligned with the findings of this study. The results indicate that the population contributes to the implementation of the Peace and Order and Public Safety (POPS) program.

The findings revealed that regardless of variables used to determine extent of implementation of the POPS program, both groups of communities identified "poor access road" as the topmost challenge which imply the lack of government intervention to accelerate delivery of services. This finding is validated by the lack of awareness of the community residents to programs and ordinances 
supported by their indifference to participate and acknowledge government programs and projects. Above all, the results still affirmed the prevalence of poverty in the communities probably due to the insufficient revenues and income of the LGU which imply the absence of a focused local revenue generation program.

\section{Suggestions of the community leaders for POPS implementation}

In crime prevention and control, the topmost suggestion was the need for community participation through education and information other than the priority need for financial resources. Other suggestions are the active participation of BPOC and Village Council in training and IEC, which imply a need for the residents' participation. These suggestions revealed by the community leaders imply that the best approach to crime management is primarily a prevention strategy rather than waging war against criminal activities (Ghani, 2017).

On anti-illegal drugs, the provision of seminars to BADAC, empowerment of residents to report information, and intensification of monitoring on illegal drugs, which suggestions find support in the studies of Agustin et al. (2019), Mendoza, Yusingco, and Gamboa (2018), and Hechanova et al. (2018) that information dissemination is a component of the government's anti-illegal drug campaign.

For public safety, the top three suggestions are the establishment of emergency hotlines in remote areas, the installation of early warning signs, and the awareness of the community.

On enforcement of ordinances, top-rated suggestions are monitoring and evaluation, participation during the public hearing, and the creation of enforcement teams. These suggestions imply a need to create teamwork to monitor the implementation of local ordinances effectively.

\subsection{Conclusion}

Strong community participation and leadership make a difference in the implementation of the Peace and Order and Public Safety (POPS) program. Policies that reduce economic and social segregation increase communities' healthy development. Therefore, government agencies should be proactive in crime prevention. The Theory of Good Governance focused on the principles of participation, efficiency, and leadership was revealed as necessary for peace and order and public safety, thereby validating the framework of this study.

The challenges encountered by the barangays and the suggestions of community leaders indicate that when the government and stakeholders participated in the implementation of a program such as the POPS, problems are minimized if not totally eliminated. Thus, it is recommended that the government should initiate and implement sound economic policies that will create employment corridors and poverty eradication and improve law enforcement agencies. Likewise, it is also very important that the municipality should consider the priority needs of its component villages in the POPS Plan, considering their limitations both in human and financial resources. The theory of the paper that the implementation of the Peace and Order and Public Safety (POPS) program is an effective community-based crime prevention mechanism and lead to a peaceful, safe, and habitable community of satisfied residents is validated.

\section{REFERENCES}

Asor, J. R., Catedrilla, G. M. B., \& Estrada, J. E. (2018, March). A study on the road accidents using data investigation and visualization in Los Baños, Laguna, Philippines. In 2018 International Conference on Information and Communications Technology (ICOIACT) (pp. 96-101). IEEE.

Agustin, C. P., Rovero, J., Paraon, C. L., Taguinod, R., \& Turingan, I. (2018). Functionality of barangay anti-drug abuse Council: its roles and responsibilities under dilg memorandum circular no. 2015-66. International Journal of Advanced Research in Management and Social Sciences, 7(2), 29-49.

Alagabia Jr, W. D., \& Cawi, R. D. The Implementation of the Anti-Drug War Campaign of the Philippine Government.

Buhaug, H. \& Tollefsen, A. F. (2015). Insurgency and Inaccessibility1. International Studies Review, 17(1), 6-25.

Carpio, C. J. (2020). Implementation of Curfew Ordinances in Cabanatuan City, Nueva Ecija. International Journal of English Literature and Social Sciences (IJELS), 5(1).

Chamlin, M. B., \& Cochran, J. K. (2004). An excursus on the population size-crime relationship. W. Criminology Rev., 5, 119.

Curiel, R. P., Delmar, S. C., \& Bishop, S. R. (2018). Measuring the distribution of crime and its concentration. Journal of quantitative criminology, 34(3), 775-803

Dekanoidze, K. \& Khelashvili - Kyiv, M. (2018). Police Education and Training Systems in the OSCE Region. Organization for Security and Co-operation in Europe Project Coordinator for Ukraine. Retrieved from https://www.osce.org/files/f/ documents/f/7/423401.pdf

Dio, R. V., Apostol, S. M. G., \& Madrazo, A. L. (2019). Drug Surrenderers and Crime Statistics during the Implementation of Project Double Barrel (PDB) in the Philippines. International Journal of Social and Administrative Sciences, 4(1), 31-43. 
Esser, F., \& Vliegenthart, R. (2017). Comparative Research Methods. In J. Matthes, C.S. Davis \&R. Potter (Eds.). The International Encyclopedia of Communications Research Methods (pp.248-269_. London:Wiley-Blackwell.

Ghani, Z. A. (2017). A comparative study of urban crime between Malaysia and Nigeria. Journal of Urban Management, 6(1), 19-29.

Gichaga, F. J. (2016). The impact of road improvements on road safety and related characteristics. IATSS research, 40(2), 72-75.

GONIS, G. I. (2018). Illicit drugs use among youth: a hindrance to socio-economic development in Rwanda. Social Research Reports, 10(2), 74-84.

Downs, A. (2004). Traffic: Why it's getting worse, what government can do (No. Policy Brief\# 128). Brookings Institution.

Habiatan, E. N. (2019). The barangay peace and order council of Cabagan, Isabela. International Journal of Advanced Research in Management and Social Sciences, 8(10), 415-441.

Hasam, M. A., \& Mushahid, M. (2017). Drug addiction in urban life of Bangladesh: A sociological study for exploring the causes. Asia Pacific Journal of Multidisciplinary Research, 5(2), 1-10.

Hechanova, M. R. M., Alianan, A. S., Calleja, M. T., Melgar, I. E., Acosta, A., Villasanta, A., ... \& Canoy, N. (2018). The development of a community-based drug intervention for Filipino drug users. Journal of Pacific Rim Psychology, 12.

Huey, L., Kalyal, H., \& Peladeau, H. (2017). Preparing police recruits of the future: An educational needs assessment.

Layug, Allan S., Pantig, Ida Marie T., Bolong, Leilanie E., and Lavado, Rouselle F., (2009). Do Barangays Really Matters in Local Service Delivery? Some Issues and Policy Options. Philippine Journal of Development, Number 27. Second Semester 2009 Volume XXXVI, No. 2 ..

Mendoza, R. U., Yusingco, M. H., \& Gamboa, J. (2018). The Role of Mayors and Barangay Captains in the Philippines' Anti-Drugs Campaign.

Patalinghug, M. (2017). Implemented Crime Prevention Strategies of PNP in Salug Valley, Zamboanga Del Sur, Philippines. Asia Pacific Journal of Multidisciplinary Research, 5(3).

Oliveira, M., Bastos-Filho, C., \& Menezes, R. (2017). The scaling of crime concentration in cities. PloS one, 12(8), e0183110.

Sackett, C. (2016). Neighborhoods and violent crime. Evidence matters. Retrieved from US Department of Housing and Urban Development website: https://www. huduser. gov/portal/periodicals/em/summer16/highlight2. html.

Severino, R. (2001). ASEAN: Building the Peace at Southeast Asia. Retrieved from https://asean.org/?static_post=asean-building-the peace-in-southeast-asia-2

United Nations Office on Drugs and Crime (2017). Prevention of Drug Use and Treatment of Drug Use Disorders in Rural Settings. Retrieved from https://www.unodc.org/documents/17-01904.Rural_Treatment_ebook.pdf

Welsh, B. C., \& Farrington, D. P. (2010). The future of crime prevention: Developmental and situational strategies. National Institute of Justice, 1-65.

Wittens, S. A. (2012). Drug Related Violence in Mexico A literature study from 1985-2011 (Masterss thesis).

Yonson, R., Noy, I., \& Gaillard, J. C. (2018). The measurement of disaster risk: An example from tropical cyclones in the Philippines. Review of Development Economics, 22(2), 736-765.

\section{Correspondence:}

RHUMYLA G. NICOR-MANGILIMUTAN

rnicormangilimutan@gmail.com

MARIA NOVE A. MEJICA

mejicanove@gmail.com

MERLITA V. CAELIAN

merlita_caelian@yahoo.com

https://orcid.org/0000-0002-4671-4047 